\title{
Science teacher education in Macau: a critical review
}

Bing Wei(D)

\author{
Correspondence: bingwei@um.edu. \\ mo \\ University of Macau, Faculty of \\ Education., Macau, China
}

\begin{abstract}
In this reviewing paper, a couple of issues concerning school science education in Macau are discussed, including science teacher education, science curriculum reform, and opportunities and challenges for science teachers. Especially, more space is devoted to the issue of science teacher development in the social context of Macau. This paper will be helpful for international readers to understand the history and current situation of science education in general and science teacher education in particular in Macau, a special administration region of China.
\end{abstract}

Keywords: Science teaching, Science learning, Science curriculum, Science teacher education, Macau

\section{School science in Macau}

\section{General background of Macau's K-12 education}

Macau is a small city of $30.5 \mathrm{~km}^{2}$, located in the south coast of China, approximately $60 \mathrm{~km}$ west of Hong Kong. It has a population of 670,900 with a percentage of $95 \%$ being ethnic Chinese (DSEC 2019). As a Portuguese colony, its sovereignty was returned to China in 1999, and now it is a special administrative region (SAR) of People's Republic of China, usually called Macau SAR. Known as the "Las Vegas" in the East, Macau SAR enjoys free market economies and its leading industry is tourism and gambling. In the colonial time, under Portuguese rule, Macau took a laissez-faire approach to school education and the decentralized education system was adopted as a response to the less developed economy. The decentralized education system in Macau featured the following characteristics: private schools predominating in the schooling system, diversity of school curriculums, no unified requirements for school graduates, and the absence of a standard career and pay structure for teachers (Tang et al. 2018). Since most of the primary and secondary schools are privately run - schools enjoy high autonomy in many aspects, such as planning the curriculum, selecting teaching materials and methods, and setting standards for graduation examinations - there is a great diversity across various schools in terms of curriculum and instruction (Xie et al. 2018). In the colonial era, there were various schooling systems, such as $6+3+2+1,6+5+$ $1,6+3+3$. After 1999, the Macau SAR government has made effort to unify those different schooling systems to the $6+3+3$ one, which is more compatible to that of the mainland China. Since the 2010s, the government of Macau SAR has provided the 15years of free education $(\mathrm{K}-12)$ according to the "Ten Year Plan for the Development

(c) The Author(s). 2019 Open Access This article is distributed under the terms of the Creative Commons Attribution 4.0 International License (http://creativecommons.org/licenses/by/4.0/), which permits unrestricted use, distribution, and reproduction in any medium, provided you give appropriate credit to the original author(s) and the source, provide a link to the Creative Commons license, and indicate if changes were made. 
of Non-Tertiary Education (2011-2020)" (DSEJ 2019). Under this scheme, those private schools in non-free systems became free ones by receiving the government grants. Currently, there are mainly three categories of schools: (1) public schools; (2) private schools in the free education system; and (3) private schools in the non-free education system. Schools in the free education system occupy $86.5 \%$ among all schools in Macau (Xie et al. 2018). As for the private schools, most are administered and operated by the Union of Catholic Schools or the Chinese Educator's Association, with the latter being assumed to have strong relationship with the central government of China (Leung 1991). The basic information of the schooling system of Macau is listed in Table 1.

\section{Science teaching and learning}

School science has long been an inseparable part of secondary education in Macau. Yet, since Macau is a small place, few scholars have been concerned about school science in this region; even research on Macau education and society does not address its curriculum or teaching issues of school science (e.g., Bray and Koo 2004). Thus, it is difficult to describe what the typical science teaching and learning is like in this region. Fortunately, based on the data of an evaluation project of science education in primary and secondary schools in Macau, the features of school science in Macau can be summarized into seven points (Wei 2016; Wei et al. 2009). First, with regard to the types and teaching hours (per week) of sciences courses offered, there were great discrepancies among the evaluated schools, with each school having a unique feature. Second, as indicated in the process of designing school-based teaching outlines, science teachers had a certain degree of autonomous power in planning daily science teaching. Third, the teaching of the science curriculum and the use of science textbooks were to a great degree influenced by the neighboring regions with the mainland China being the most influential one, reflecting the remarkable impact of the university admission examinations on school science curriculum and teaching. Fourth, routine science teaching was reliant on textbooks but the students-centered teaching ideas and strategies implicated in the textbooks had not been implemented in practice. Fifth, science teachers dominated science classes and lecturing was the most prevalent teaching method, with few opportunities provided for the interactions between teachers and students. Sixth, neither the regular classroom environment nor the laboratory environment was fully consistent with the constructivist tenets in the views of students: science teaching is not highly relevant, students are passive in learning, the extent of openness of laboratory work is low, and students had few opportunities to give opinions on science teaching. Seventh, students had positive attitudes to science, and had interest in school science, but few students opted to choose science as their college majors owing to the worries of few job opportunities in science or related industries in Macau.

Table 1 The basic information of the schooling system of Macau (Source: DSEJ, 2019)

\begin{tabular}{lllll}
\hline & Schools & Teachers & Classes & Students \\
\hline Public schools & 10 & 357 & 171 & 2707 \\
Private schools in the free education system & 54 & 5882 & 2342 & 66,443 \\
Private schools in the non-free education system & 10 & 545 & 247 & 7196 \\
Total & 74 & 6784 & 2760 & 76,346 \\
\hline
\end{tabular}


As a member of the Organization for Economic Cooperation and Development (OECD), Macau SAR has participated in the Program for International Student Assessment (PISA) since 2003. Students' performances in the PISA over the years provided reliable data on science teaching and learning in Macau. According to the PISA results in 2015, among the 70+ participating countries/regions, Macau's 15-years-olds' scientific literacy performance ranked sixth and was significantly above the OECD average (Cheung, et al. 2016). Moreover, the data shows that Macau's 15-year-students' overall performance on scientific literacy performance has been steadily improved across the five circles of PISA assessment (i.e., PISA 2003, PISA 2006, PISA2009, PISA 2012, and PISA 2015) (Cheung et al. 2016). The performances of Macau's 15-year-olds in PISA 2015 not only reflected the actual state of school science in Macau but also shed light on the problems and challenges encountered by science teaching and learning in this region. Compared with economies in neighboring regions, for instance, Macau has a lack of top-performing students in science and technology (Cheung et al. 2016).

\section{Science teacher education}

Teacher education emerged as a part of the high education system in the nineteenth century. Compared with other professions such as law and medicine, obviously, it was very late. According to Hayhoe (2016), the contemporary teacher education began to be integrated in universities in France in the twentieth century. According to Vong (2014), teacher education in the history of Macau has experienced a transition from a "drifting" and "discursive" mode to a normalized and systematic one. The commence of the integrations of teacher education with high education institutions in this region can be dated back to 1985, when teacher education programs were offered by South China Normal University (SCNU) from China (Vong 2014; Vong and Wong 2010). In 1987, local in-service training programs were offered for primary and pre-primary teachers in University of Eastern Asia, the predecessor of University of Macau (UM), which obtained the current name in 1991. In 1989, Faculty of Education (FED) was established in this university and become the first educational faculty in Macau. Since then, a couple of four-year teacher education programs with Bachelor's degree have been offered one after another in FED. Currently, there are six pre-service teacher preparation programs in FED, University of Macau, they are: (1) Chinese education of secondary school; (2) English education of secondary school; (3) Mathematics education of secondary school; (4) Integrate science education; (5) Primary education; and (6) Preprimary education. Besides these pre-service teacher preparation programs, there is the Postgraduate Certificate of Education (PGCE) program. For people who hold Bachelor's degree but have not received teacher education in their universities, they can be enrolled in this program. PGCE is recognized by the Education and Youth Affairs Bureau (the top educational administration of Macau SAR, usually called DSEJ in Portuguese) as a teacher license in Macau SAR. Besides FED of University of Macau, other two local higher education institutions also provide teacher education programs, they are: Institute of Macau Polytechnic (specializing in Arts and Physical Education) and St Joseph University (Cheng 2018). However, neither of them provide science related teacher education programs.

Among those Bachelor' degree teacher preparation programs, "Integrated Science" is a newly opened program. This new program has been set to respond to the situation 
that there was no pre-service science teacher education program in Macau and local science teachers had to receive their full-time teacher preparation education in normal universities in mainland China or Taiwan. The opening of the "Integrated Science" program is significant because it is the first science teacher preparation program in the history of Macau. This pre-service science teacher education program is jointly offered by FED and other science related Faculties in UM and it is run by FED. The rationale of the program is to provide prospective science teachers with integrated areas of sciences and its purpose is to provide qualified science teachers for both junior and senior secondary schools in Macau. It is declared that the new program "will meet the educational needs and leverage developmental growth in Macao" and "addresses and fulfills the professional demands outlined for science education as formulated in 'Curriculum Framework for Formal Education of Local Education System' and 'Requirements of Basic Academic Attainments of Local Education System' required by the Macao SAR government" (FED (Faculty of Education, UM), 2019). Like other pre-service teacher preparation programs in FED, students who graduate from this program are endorsed by DSEJ as qualified secondary school teachers. Specially, students who complete the compulsory courses of this program are qualified to teaching science in junior secondary schools; students who take one area of biology, chemistry, or physics as their specialization are assumed to be eligible to teach biology, chemistry, or physics in senior secondary schools. This new program has admitted high school graduates in the autumn of 2019. The total credit of this program is 132 and its constituent courses can be classified into five categories, they are: (1) General education; (2) Educational foundation; (3) Science content; (4) Pedagogy of science; and (5) Teaching practice. The details of this science education program are listed in Table 2.

\section{Science curriculum reform}

\section{Curriculum reform policies}

Since the return of sovereignty to China, the Macau SAR Government has exercised control over education and attempted to make new educational policies, which represents a move towards centralization (Tang et al. 2018; Vong 2014). In 2006, the government of Macau SAR stipulated the Non-Tertiary Education System Law (The Law of Number 9/2006, Macau) with the purpose of establishing a new system of $\mathrm{K}-12$ education and ensuring the quality of schooling in this special administrative region of China. As stipulated in this law, to extensively enhance the scientific and humanistic literacy of citizens is clearly stated as one of the general objectives of K-12 education. In 2009, DSEJ launched a blueprint in response to the development of society, economy and culture, which symbolized the initiation of non-tertiary education curriculum reform at Macau. A couple of years later, DSEJ issued an administrative regulation in 2014, entitled Curriculum Framework for Formal Education of Local Education System (No.15/2014). In the proposed curriculum framework, there are six learning domains, they are: (1) language \& literature; (2) mathematics; (3) people, society and the humanity; (4) science and technology; (5) physical education and health; and (6) arts. Each of them is composed of various subjects and "natural sciences" is included within the domain of "science and scientific technology" as a subject for junior and senior secondary schools. For each subject, the Requirements of Basic Academic Attainments (RBAA) is 
Table 2 The details of the Integrated Science program (Source: FED, 2019)

\begin{tabular}{|c|c|c|}
\hline Courses categories & Courses & Credits \\
\hline $\begin{array}{l}\text { General education and } \\
\text { free electives }\end{array}$ & $\begin{array}{l}\text { (According to UM, undergraduate students should learn eight } \\
\text { general-education courses in four areas - Global Awareness, Literature } \\
\text { and Humanities, Science and Technology, and Society and Behaviors, } \\
\text { and they can select any courses provided by home faculty or other } \\
\text { faculties as free elective) }\end{array}$ & $51(38.6 \%)$ \\
\hline Educational foundation & $\begin{array}{l}\text { Introduction to Education; Educational Psychology; Sociology of } \\
\text { Education; Introduction to Special Education; Teacher Ethics and } \\
\text { Teacher Professional } \\
\text { Development; School Counseling and Guidance }\end{array}$ & $18(13.6 \%)$ \\
\hline \multirow[t]{4}{*}{ Science content } & $\begin{array}{l}\text { Introduction to Biological Sciences; College Physics; Electromagnetism } \\
\text { and Physical Optics; Introduction to College Chemistry; Advanced } \\
\text { Mathematics I; Analytical and Environmental Chemistry; Advanced } \\
\text { Mathematics II; General and Clinical Microbiology; Earth and Universe; } \\
\text { Genetics and Epigenetics; Inorganic Chemistry }\end{array}$ & $3345(34.1 \%)$ \\
\hline & $\begin{array}{l}\text { General and Clinical Biochemistry; Cell and Molecular Biology; } \\
\text { Physiology and Pathophysiology; Development and Aging } \\
\text { (Specialization in biology) }\end{array}$ & \multirow[t]{3}{*}{12} \\
\hline & $\begin{array}{l}\text { Physical Chemistry; Materials Physics and Chemistry; Organic and } \\
\text { Polymer Chemistry; Nano chemistry (Specialization in chemistry) }\end{array}$ & \\
\hline & $\begin{array}{l}\text { Quantum Physics; Thermodynamic and Statistical Physics; Solid State } \\
\text { Physics; Low-dimensional Physics (Specialization in physics) }\end{array}$ & \\
\hline Pedagogy of science & $\begin{array}{l}\text { Science Education in Secondary Schools; } \\
\text { Scientific Inquiry and Practical Work in Secondary } \\
\text { Schools; Assessment in Science Education; Emerging Pedagogies of } \\
\text { STEM Teaching }\end{array}$ & $12(9.1 \%)$ \\
\hline Teaching practice & Supervised Teaching and School Experience & $\begin{array}{l}6 \\
(4.5 \%)\end{array}$ \\
\hline Total & & 132 \\
\hline
\end{tabular}

adopted as the curriculum form, which includes the rationale for the subject, curriculum goals, and specific items in subject content. Moreover, it is stipulated that the total lengths of teaching activities of junior and senior nature sciences are no less than 12, 360 and 5, $600 \mathrm{~min}$ respectively. In the following sub-section, the constituent parts of the RBAAs for junior and senior secondary schools will be introduced.

\section{The rationale of natural sciences}

The notion of scientific literacy was set as the central goal of the RBAA for both junior and senior secondary schools. This was based on the following two considerations (Wei, 2018a). Firstly, as stipulated in the Non-Tertiary Education System Law, raising the level of scientific literacy of all students is one of the general goals of pre-college educational enterprise in Macau. Secondly, scientific literacy has been described as the overall aim, or general purpose, of science education in recent decades in the field of science education (Bybee 1997; Laugksch 2000; Miller 1996; Norris and Phillips 2003) and it has been used as a central theme in selecting science curriculum content and recommending teaching methods in some internationally influential science education innovations, such as Project 2061 (AAAS 1989), National Science Education Standards (NSES) (NRC (National Research Council), 1996), and Next Generation of Science Education (NGSS Lead States 2013). On the basis of the existing literature on science curriculum, it can be concluded that the scientific literacy education is for all students; scientific literacy oriented science education places emphasis on the connection among 
subjects and also the interaction between science and the contemporary society and students' daily lives; and in its teaching methods, the scientific inquiry and students' self-regulated learning are the main focus (Wei 2018a). Informed of these ideas of science education, three "basic curriculum ideas" were set up for the RBAAs in order to achieve the central goal of scientific literacy oriented education:

a) Aiming at promoting students' overall development, enabling the improvement of every student's level of scientific literacy.

b) Strengthening the connections between different disciplines, helping students understand the relationship between science, technology and society.

c) Laying stress on the diversification of teaching methods, and actively promoting inquiry learning.

\section{Curriculum goals}

Derived from those "basic curriculum ideas", the curriculum goals have been proposed for junior and senior secondary schools respectively. For instance, there are seven curriculum goals in the RBAA for junior secondary schools:

a) Maintain and develop students' curiosity and craving for knowledge about natural phenomena; reinforce their interests in and passion for learning science.

b) Allow students to understand basic scientific knowledge; be able to explain common natural phenomena by using relevant scientific concepts and principles.

c) Help students master some basic scientific methods and skills; guide them to solve practical problems related to natural science.

d) Lead students to realize the significance and basic process of scientific inquiry; enhance their experience in and develop their primary ability of scientific inquiry.

e) Enable students to gradually cultivate such scientific spirit as constant thinking, daring to question, being rigorous in searching for the truth, willing to practice and being good at cooperating with others.

f) Guide students to comprehend the relationship between science, technology, society and environment; pay attention to science-related social issues to allow them to initially form the awareness of actively participating in the discussion of social issues.

g) Lead students to understand the nature of science, nurturing their awareness of applying scientific knowledge, methods, and attitude in viewing and solving personal and social issues.

\section{Subject content}

According to Roberts (2007, 2011), the notion of scientific literacy expresses a composite concept of science education and there are two visions of scientific literacy: while scientific literacy I represents the discipline of science (the products, processes, and characteristics of the scientific enterprise), scientific literacy II reflects social and cultural applications of science. Suggested by the theory of learning progression, it can be argued that the former is the foundation of the latter. In Macau, the junior high school is the later stage of the compulsory education, which means that junior high schools 
should provide students with a common foundation for science learning. Comparatively speaking, senior secondary school students are more diverse in their choices of learning streams, including science, art, and business. In fact, it is not realistic to require all senior secondary school students to learn science disciplinary knowledge because science as a subject is not offered for those students in the streams of arts and business in some of senior secondary schools in Macau. Based on Roberts' two visions of scientific literacy and the realistic situation of diversified school-based curriculums, a compromise was made: vision I is used to construct the RBAA for junior secondary schools whereas vision II for senior secondary schools. Some specifics were taken into account. First of all, since the notion of scientific inquiry embodies the processes of scientific discovery and reflects the characteristics of the scientific enterprise, it should not be absent from the RBAA for either junior or senior secondary schools. The second consideration was that subject content of science for junior secondary schools was selected from four traditional science subjects (physics, chemistry, biology, and physical geography). Therefore, the four learning areas were identified for the RBAA for junior secondary schools, they are: (1) scientific inquiry; (2) physical science; (3) life science; and (4) the earth and space sciences. They were further divided into 12 categories of items. Thirdly, in the stage of senior secondary schools, suggested by vision II of scientific literacy, the subject content of science was focused on the situations where "science demonstrably plays a role in human affairs" (Roberts 2011, p. 12). Thus, the RBAA for senior secondary schools are constructed in the four learning areas: (1) scientific inquiry; (2) the history and the nature of science; (3) environments and resources; and (4) modern technology. The learning domains and categories of the RBAAs for junior and senior secondary schools are listed in the Table 3.

The RBAAs for junior and senior secondary schools were promulgated by DSEJ in 2017 and they came into effect in the fall of that year.

\section{Opportunities and challenges for science teachers Opportunities}

Professional training requirements and the job market for school teachers is two key aspects of young people's consideration of entry into teaching. Han et al. (2018) analyzed

Table 3 The learning areas and categories of the RBAAs for junior and senior secondary schools

\begin{tabular}{lll}
\hline Junior secondary schools & & Senior secondary schools \\
\hline Scientific inquiry & Understanding of scientific inquiry & Scientific inquiry \\
Physical Sciences & $\begin{array}{l}\text { Substances in everyday life } \\
\text { Material properties and structures }\end{array}$ & The history and the nature of science \\
& Movement and interaction of substances \\
& Energy and energy sources & \\
& The structure of organisms \\
Vife science & Human bodivities of organisms and health & \\
& Ecology and evolution & \\
The Earth and Space sciences & $\begin{array}{l}\text { The Earth } \\
\text { Composition of the Universe }\end{array}$ & \\
\hline
\end{tabular}


cross-national data from the PISA 2015 and examined the relationship between secondary school students' career expectations and the job characteristics and societal evaluations of teaching. They found that "teacher salaries and societal evaluations about the importance of job responsibility and respect are positively associated with teaching career expectations, while working hours are negatively associated with teaching career expectations" (pp. 3-4). As we know, Macau is a small city with tourism and gambling as the major industry, which offers numerous job opportunities. Especially, with the liberalization of the gambling industry in 2001, significant investment inflow was induced, which resulted in rapid growth of the economy. Compared with the adjacent regions, the unemployment rate in Macau is very low. Thus, it is understandable that teaching was not an attractive career choice for young graduates from universities. However, this situation has changed in recent years. In a comparative study on the reasons for pre-service student teachers becoming teachers in Hong Kong and Macau, Tang and their colleagues (2018) found that student teachers in both societies share commonality in their altruistic and intrinsic motivations and student teachers' motivations reflected the different educational systematic factors in the two special administrational regions of China. In Macau, as indicated by Tang et al., the "government-initiated quantitative expansion and quality enhancement in education" (p. 442) provides social contexts where student teachers perceived teaching profession with great prospects. The finding of this study is echoed by a statistical report, which indicates that the number of high school graduates choosing to study in teacher preparation programs provided by universities has been steadily increased from 2012 to 2016 (DSEJ 2019).

Since the Macau SAR was established in 1999, the new government has exercised greater responsibility for and control over education. The importance of teacher development has been recognized by the Macau SAR government and teachers' professionalization is often projected in the Chief Executive Annual Policy Addresses. A large variety of measures and strategies have been introduced to address quality concerns, including initiating new education regulations and rules, centralizing the curriculum system in K-12. Especially, summarized by Vong and Yu (2017), various measures have been taken to enhance teachers' professionalization in recent years. First, the government continues to give financial support and resources are continually provide to lessen teachers' non-teaching workload and to improve their working conditions. Second, more learning opportunities are offered to mid-level school management teams in order to build up effective school practice for all teachers. Third, various training programs are provided by DSEJ to upgrade teachers' qualification and expertise. In the case of science education, UM has hosted a variety of in-service science teacher training programs and projects in recent years, most of which were commissioned or supported by DSEJ. These programs and projects include: (1) the science lab technician training program; (2) the history and philosophy of science (HPS) in science teaching; (3) the STEM education training programs for primary and secondary science teachers; (4) science teaching workshops on the RABBs for junior and senior secondary schools; and (5) lectures on advanced science content. More importantly, to maintain a sustainable teaching profession development, a career framework for private school personnel, called System Framework for Private School Teaching Staff of Non-tertiary Education has been established and come into effect in 2012. In this framework, multiple 
measures and practices have been introduced, such as enhancing appointment requirements, establishing the career regime, promoting professional development, and ensuring remuneration (DSEJ, 2012). For example, in the System Framework, six scales of teachers' professional rank are stipulated and 30-h training is needed for a teacher to promote from a current scale to a higher one. According to Vong and Wong (2010), these measures can be seen as actions to construct professionalization and to reconstruct the teaching profession in Macau.

The science curriculum reform has constituted another opportunity of science teacher development. In Macau, as mentioned earlier, most of secondary schools are run by private organizations and associations and they have their own curriculum and instruction systems for natural sciences. At the junior secondary level, biology, chemistry, and physics are taught in most of secondary schools but the teaching hours for each subject are diversified among these schools. At the senior secondary level, the diversity of school science curricula is even greater. In some schools, students are separated into the science and the arts streams and no natural science courses are provided for those students in the arts stream. In the Curriculum Framework for Formal Education of Local Education System, minimum of teaching hours have been stipulated for both junior and senior secondary schools. Especially, it is stipulated that science should be offered for all student including those in the arts stream in senior secondary schools. Furthermore, in the RBAAs for junior and senior secondary schools, the importance of the school science in raising civilian scientific literacy has been highly advocated, which set the backdrop of recognizing the social status of school science teachers in Macau. In view of teacher learning (Franser et al. 2007; Wallace and Loughran 2012), the RBAAs provide science teachers with chances of learning the advanced ideas, subject content, and innovative teaching methods in the area of science education.

\section{Challenges}

The challenges for science teachers in Macau come from several aspects. The first is about the emergent subject matter knowledge of science. As we know, subject matter knowledge has long been concerned by many scholars since it is the subject matter that make meaningful for students and help them attain educational objectives (Deng 2007). In the field of teacher education, Shulman (1986) conceptualized teachers' subject matter knowledge in terms of content knowledge, pedagogical content knowledge (PCK), and curricular knowledge. Later on, Grossman et al. (1989) further proposed that content knowledge should encompass four components: content knowledge, substantive knowledge, syntactic knowledge, and beliefs about the subject matter. As introduced earlier, the RBAA for junior secondary schools is mainly focused on traditional science content; however, in the RBAA for senior secondary schools, the learning areas are inclusive of "history of science and the nature of science", "environment and resources", and "modern technology". For most of science teachers in Macau who were trained in the traditional science teacher education programs, they are not familiar with these new kinds of science content that takes a humanistic perspective (Aikenhead 2006).

The second challenge is related to scientific inquiry. As mentioned previously, the notion of scientific inquiry has been advocated as both science content and a teaching mode in the two RBAAs of science for junior and secondary schools. Once more, for 
most of science teacher, scientific inquiry constitutes a new component of subject matter knowledge, which is strange to them. Therefore, they need to learn the meanings of scientific inquiry and further develop the relevant PCK in teaching practice. A related challenge is that they should learn to use the emergent STEM related pedagogies in recent years. In Macau, private schools usually gain social reputation by participating in public activities. In the case of science, school principals are willing to encourage their students to take part and win awards in the various types of science contests and competitions organized by the local, national or international organizations, most of which are hands-on and involve new technologies such as Robotics, Artificial Intelligence (AI). For most science teachers, however, they feel pressed to guide their students to participate in these STEM related science contests and competitions because they themselves are not good at doing these activities.

The third challenge is accompanied by the implementation of the integrated science, which was identified as a distinct feature of contemporary science education (Wei, 2015). Traditionally, science curriculum was offered in separate forms, i.e., biology, chemistry and physics in most of secondary schools in Macau. In recent years, more and more junior secondary schools are attempting to replace separate sciences by the integrated science under the influence of Hong Kong, where the integrated science is adopted as the science curriculum at the junior level, and mainland China, where attempts have been made to promote the integrated science in the junior secondary schools (Sun et al. 2014; Wei 2009, 2018b). The implementation of integrated science curriculum requires every teacher to teach the content knowledge of all science subjects including that beyond their own subjects. Therefore, science teachers are in face of the issue of updating their knowledge structure when they start to teach the integrated science curriculum. Especially, they have to struggle at the very beginning in handling multiple-subject knowledge content as they found themselves owning a fairly limited knowledge except their own subject fields.

\section{Concluding remarks}

In this reviewing paper, I have discussed a couple of issues relevant to school science education with a focus on science teacher education in Macau, the former Portuguese colony in Asia. Due to some historical reasons, school science in Macau is unique in many aspects. For a long period of time, science teacher education in this region was neither normalized nor systematic, mostly manifesting in the lack of formal science teacher preparation programs till the opening of the Integrated Science program in the Faculty of Education, University of Macau in 2019. As we know, science teacher education is a long-term and comprehensive enterprise and it needs the cooperation of and connections between the government, school administration, and individual science teachers. In Macau, since the sovereignty returning to China in 1999, the SAR government has a strong willingness to address quality concerns in education with various government-initiated reforms. Among those various initiatives, two are closely related to teacher education. The first is the initiation of the law on the System Framework for Private School Teaching Staff of Non-Tertiary Education, which is assumed to ensure the quality of school education and teachers' professional development. As a general official document on teacher development, the System Framework is playing an important role in guaranteeing private school teachers' benefits and rights. However, since it 
does not involve any details about the structure and curricula of teacher education, it is not realistic to expect it to change the fragmented, drifting and discursive situation of teacher education in Macau (Vong 2014).

The second is the implementation of the Requirements of Basic Academic Attainments for school subjects under the Curriculum Framework for Formal Education of Local Education System (No.15/2014). As for the case of science, the RBAAs for natural science in junior and senior secondary schools have clearly and explicitly defined the role of natural sciences in the secondary schools and set up the first basic framework of science education in the history of Macau. The implementation of the RBAAs has provided opportunities for science teacher to learn the new kinds of subject matter knowledge and student-centered teaching methods and strategies. However, for individual science teachers, who was educated in compartmentalized departments of science (e. g., biology, chemistry, and physics) in university, they have to face a variety of challenges, such as unfamiliarity with the emergent subject matter knowledge (the history and nature of science, and science related social issues), which is defined from a humanistic perspective, and the understanding and enactment of scientific inquiry that is advocated in the RBAAs. In addition, with the STEM oriented innovations and the advocating of the integrated science in many junior schools in recent years, some teachers feel difficult to deal with them in practice. Hopefully, these issues and problem will be solved by the collaborative work between the higher institutes and local schools with the support of the Macau SAR government.

As mentioned earlier, Macau is a unique Chinese society, which has been shaped by the tradition Confucian culture and Western values and lifestyles. Keeping this in mind, I must say that some of the opportunities and challenge faced by science teachers in Macau have been seen in other countries and regions around the world while some are closely related to the history, culture and economy of this small city in eastern Asia. Unfortunately, empirical research is so absent in science education in Macau that no sufficient data can be used to illustrate the uniqueness of this city. In the future, empirical studies should be conducted to provide more evidence in demonstrating school science in Macau and comparing science teacher education in this region with that in the rest of the world.

Acknowledgements

No

Authors' contributions

The author read and approved the final manuscript.

Authors' information

Bing Wei is associate professor of science education in the faculty of education, University of Macau. His research interests include social contexts of science curriculum, scientific literacy, history and philosophy or science and science teaching, and science teacher development. His research research work appear in Science Education, International Journal of Science Education, Research in Science Education, Chemistry Education Research and Practice, and School science and Mathematics. He also published several book chapters in English.

Funding

No

Availability of data and materials

All data discussed is available from sources cited in the paper. The data sets can be made available from the corresponding author on reasonable request. 


\section{Consent for publication}

The authors agree that this article will be published in the APSE journal.

\section{Competing interests}

The authors declare that they have no competing interests to report.

Received: 9 August 2019 Accepted: 5 November 2019

Published online: 02 December 2019

\section{References}

AAAS (American Association for the Advancement of Science) (1989). Project 2061-Science for all Americans. Washington, DC: AAAS.

Aikenhead, G. S. (2006). Science education for everyday life: Evidence-based practice. Teachers College Press.

Bray, M., \& Koo, R. (2004). Education and society in Hong Kong and Macau: Comparative perspectives on continuity and change (2nd ed.). Hong Kong: The University of Hong Kong.

Bybee, R. W. (1997). Towards an understanding of scientific literacy. In W. Graber \& C. Bolte (Eds.), Scientific literacy (pp. 37-68). Kiel, Germany: Institute for Science Education (IPN).

Cheng, C. W. (2018). A review of the recent development of Chinese language teachers' education in Macao. The Journal of Society for Humanistic Studies in East Asia, 44, 49-70 (in Chinese).

Cheung, K. C., Sit, P. S., Mak, S. K., \& leong, M. K. (2016). Macao-PISA 2015 report: Assessment of scientific, reading, mathematical literacy performance of 15-year-old students from an international comparison perspective. Macau: Educational Testing and Assessment Research Centre, University of Macau.

Deng, Z. (2007). Knowing the subject matter of a secondary-school science subject. Journal of Curriculum Studies, 39(5), 503-535.

DSEC (2019). The statistic data of the population in Macau. Available: http://www.dsec.gov.mo.

DSEJ (2012). The System Framework for Private School Teaching Staff of Non-tertiary Education. . Available: http://www.dsej.gov.mo

DSE (2019). The statistic data of high school graduaters choosing to study in higher education. Available: http://www.dsej.gov.mo. FED (Faculty of Education, UM) (2019). The Integrated Science Program. Available: http://www.um.edu.mo/fed/.

Franser, C., Kennedy, A., Reid, L., \& Mckinney, S. (2007). Teachers' continuing professional development: Contested concepts, understandings and models. Journal of In-service Education, 33, 153-169.

Grossman, P. L., Wilson, S. M., \& Shulman, L. S. (1989). Teachers of substance: Subject matter knowledge for teaching. In M. C. Reynolds (Ed.), Knowledge base for the beginning teacher (pp. 23-36). New York: Pergamon.

Han, S. W., Borgonovi, F., \& Guerriero, S. (2018). What motivates high school students to want to be teachers? The role of salary, working conditions, and societal evaluations about occupations in a comparative perspective. American Educational Research Journal, 55(1), 3-39.

Hayhoe, R. (2016). The idea of the Normal University and the University of Education: Implications for a Confucian pedagogy. In J. C.-K. Chi-Kin Lee \& C. Day (Eds.), Quality and change in teacher education: Western and Chinese perspectives. Dordecht, Netherlands: Springer.

Laugksch, R. C. (2000). Scientific literacy: A conceptual overview. Science Education, 84(1), 71-94.

Lead States, N. G. S. S. (2013). Next generation science standards: For States, by States. Washington, DC: The National Academies Press.

Leung, J. Y. H. (1991). Gaming, governance and public policy in Macao. Hong Kong University Press.

Miller, J. D. (1996). Scientific literacy: For effective citizenship. In R. E. Yager (Ed.), Science/technology/society as reform in science education (pp. 185-204). New York: Albany.

Norris, S. P., \& Phillips, L. M. (2003). How literacy in its fundamental sense is central to scientific literacy. Science Education, $87(2), 224-240$.

NRC (National Research Council). (1996). National science education standards. Washington, DC: Author.

Roberts, D. A. (2007). Scientific literacy/science literacy. In S. K. Abell \& N. G. Lederman (Eds.), Handbook of research in science education (pp. 729-780). Mahwah, NJ: Lawrence Erlbaum.

Roberts, D. A., (2011). Competing visions of scientific literacy: The influence of a curriculum policy image. In C. Linder, Östman, L., Roberts, A., D., Wickman, P., \& Erickson, G., \& MacKinnon (eds.), Exploring the landscape of scientific literacy (pp. 11-27). London: Routledge.

Shulman, L. S., (1986). Those who understand: Knowledge growth in teaching. Educational Researcher, 15(2), 4-14.

Sun, D., Wang, Z. H., Xie, W. T., \& Boon, C. C. (2014). Status of integrated science instruction in junior secondary schools of China: An exploratory study. International Journal of Science Education, 36(5), 808-838.

Tang, Y. F., Wong, P. M., Wang, K. Y., \& Cheng, M. H. (2018). What attracts young people to become teachers? A comparative study of pre-service student teachers' motivation to become teachers in Hong Kong and Macau. Asia Pacific Education Review, 19, 433-444.

Vong, S. K. (2014). An archeological and genealogical study of Macao teacher education policy. Journal of South China Normal University, 14(6), 50-55 (in Chinese).

Vong, S. K., \& Wong, M. W. (2010). Made in Macao: How history, politics and teachers frame curriculum practice. Curriculum and Instruction Quarterly, 13(4), 61-109.

Vong, S. K., \& Yu, W. M. (2017). Is teacher education at risk? A tale of two cities - Hong Kong and Macau. Compare: A Journal of Comparative and International Education, 48, 785-800.

Wallace, J., \& Loughran, L. (2012). Science teacher learning. In B. J. Fraser, T. Tobin, \& C. McRobbie (Eds.), Second international handbook of science education (pp. 295-306). Dordrecht, The Netherlands: Springer.

Wei, B. (2009). In search of meaningful integration: The experiences of developing integrated science curriculum in junior secondary schools in China. International Journal of Science Education, 31, 259-277.

Wei, B. (2015). Integrated science. In R. Gunstone (Ed.), Encyclopedia of science education (pp. 527-529). New York: Springer.

Wei, B. (2016). School science teaching and learning in Macau: Problems and challenges. In M.-H. Chiu (Ed.), Science education research and practice in Asia - challenges and opportunities (pp. 55-70). New York: Springer. 
Wei, B. (2018a). Scientific literacy oriented education in Macau: A retrospect of designing the RBAAs of natural sciences for secondary schools. Journal of Macau Studies, 90, 99-106 (in Chinese).

Wei, B (2018b). An exploratory study of teacher development in the implementation of integrated science curriculum. Research in Science Education. (Online first 15/09/2018).

Wei, B., Shieh, J. J., Sze, T. M., Chan, I. N., Yuen, P. K., \& Lee, M. Y. (2009). The report of the evaluation on science education in primary and secondary schools in Macau. Macau: University of Macau (in Chinese)

Xie, H., Ng, W. S., Zou, D., \& Wang, F. L. (2018, July). A comparative study on recent educational policy changes of primary and secondary schooling in Hong Kong and Macau. In 2018 International symposium on educational technology. DOI https://doi.org/10.1109/ISET.2018.00034.

\section{Publisher's Note}

Springer Nature remains neutral with regard to jurisdictional claims in published maps and institutional affiliations.

Submit your manuscript to a SpringerOpen ${ }^{\circ}$ journal and benefit from:

- Convenient online submission

Rigorous peer review

- Open access: articles freely available online

- High visibility within the field

- Retaining the copyright to your article 